\title{
Alternative Forms of Storage Protection: Biological Insecticides for the Control of the Cigarette Beetle (Lasioderma serricorne) and the Tobacco Moth (Ephestia elutella)
}

by

Hans-Jochen Eberbardt

Verband der Cigarettenindustrie

Königswinterer Straße 550

D. 53227 Bonn

\section{SUMMARY}

A large number of physical and chemical pest control methods have been developed up to now in order to ensure the effective protection of stored tobacco and tobacco products. These methods include the use of fumigants and insecticides, treatment of baled tobacco in cold chambers, monitoring the extent of infestation with pheromone traps and, the most important preventive measure of all, maintaining a strict programme to ensure hygienic storage conditions. To date, very little serious consideration has been given to the practical use of biologically based insecticides in storage pest control. Compared with synthetically-produced pesticides, however, they often have the advantage of being significantly less toxic to users and the environment, while retaining a comparable level of effectiveness on the target organism. One reason for this neglect may certainly be found in the somewhat higher price of bioinsecticides. Another hurdle is presented by the complex mixture of different biological pesticides, which makes it more difficult to obtain official approval for their use in some countries. One possible alternative is, for example, the use of Bacillus

Received: 14th April 1997 - accepted 18th June 1997 thuringiensis (B.t.) endotoxin preparations. The insecticidal activity of certain B.t. kurstaki or B.t. tenebrionis strains against the tobacco moth and cigarette beetle has already been sufficiently documented. Recent research has also looked at the possibility of using natural substances, such as extracts from the neem tree (Azadirachta indica), as storage protectants. Another very promising development is based on the autodissemination technique, whereby a modified pheromone trap in combination with entomopathogenic viruses or fungi could help to achieve a dramatic increase in mortality rates in stored tobacco pests. The chemical and biological properties of these bioinsecticides will be presented here and their advantages and disadvantages as storage protectants for tobacco discussed.

\section{ZUSAMMENFASSUNG}

In der Vergangenheit wurden zum wirksamen Schutz von gelagertem Tabak und Tabakwaren zahlreiche physikalische und chemische Bekämpfungsmaßnahmen entwickelt. Hierzu gehören der Einsatz von Begasungsmitteln und Insektiziden, die Behandlung der Tabakballen in Kältekammern, die Überwachung der Befallstärke mit Pheromonfallen und als wichtigste prophylaktische Maßnahme überhaupt, die strikte Einhaltung eines wirksa- 
men Hygieneprogrammes. Insektizide auf biologischer Basis fanden bisher für eine praktische Anwendung im Vorratsschutz nur wenig Beachtung. Sie bieten jedoch im Vergleich zu den synthetisch hergestellten Pestiziden den Vorteil, einer oftmals wesentlich geringeren Toxizität für den Anwender und die Umwelt, bei ähnlich hoher Wirksamkeit für den Zielorganismus. Ein Grund hierfür mag sicher in dem etwas höheren Preis der Bioinsektizide zu suchen sein. Andererseits bereitet auch die komplexe Zusammensetzung vieler biologischer Schädlingsbekämpfungsmittel in manchen Ländern Schwierigkeiten bei der Zulassung. Eine mögliche Alternative bietet sich beispielsweise in der Verwendung von Bacillus thuringien. sis-Endotoxin Formulierungen an. Die insektizide Aktivität bestimmter $B$. $t$. kurstaki- bzw. $B$. t. tenebrionisStämme gegen Tabakmotte und Tabakkäfer ist bereits ausreichend dokumentiert. Auch Naturstoffe, wie die Extrakte des Neem-Baumes (Azadirachta indica) werden neuerdings auf ihre Verwendungsmöglichkeit als Vorratsschutzmittel ïberpriff. Eine weitere vielversprechende Entwicklung basiert auf der Anwendung der Autodisseminationstechnik, bei der eine abgewandelte Pheromonfalle in Kombination mit insektenpathogenen Viren zu einer drastischen Erhöhung der Mortalitätsraten der Vorratsschädlinge des Tabaks beitragen könnte. Die chemischen und biologischen Eigenschaften dieser Bio insektizide werden vorgestellt und ihre Vor- und Nachteile bei der Anwendung als Vorratsschutzmittel für Tabak diskutiert.

\section{RESUME}

Dans le passé de nombreux moyens de lutte physique et chimique contre les parasites du tabac et les produits du tabac ont été développés pour garantir une protection effective des stocks. Parmi ceux-ci comptent l'emplois de fumigants et d'insecticides, le traitement des balles du tabac dans des chambres à froid, la surveillance du degré d'infection à l'aide de pî̀ges de phéromone et, avant tout, ce qui est la mesure prophylactique la plus importante, le strict respect d'un program d'hygiène effectif. Jusqu'à présent l'emplois d'insecticides biologiques pour la protection des stocks jouait un rôle négligeable. Comparé aux pesticides synthétiques ceux-ci sont souvent considérablement moins toxiques pour l'utilisateur et l'environnement mais ils garantissent tout de même une efficacité comparable à celle des pesticides synthétiques. Une raison pour l'emplois rarissime d'insecticides biologiques est sûrement le prix légèrement élevé, mais aussi le mélange complexe de constituants qui complique l'agrément de ces insecticides dans quelques pays. L'emplois de formulations de 'Bacillus thuringiensis endotoxine', est un moyen alternatif possible. L'activité insecticide de certaines souches de B.t. kurstaki ou B.t. tenebrionis contre la mite du tabac et le coléoptères de tabac est suffisamment documentée. L'efficacité des produits naturels comme les extraits de l'arbre de neem (Azadiracbta indica) est également investiguée. Un autre développement prometteur est basé sur l'emplois d'une technique d'autodissemination. Dans ce cas un piège de phéromone modifié et combiné avec des virus ou des champignons entomopathogènes pourrait contribuer à obtenir une augmentation énergique des taux de mortalité des parasites des stocks de tabac. Les propriétés chimiques et biologiques de ces bioinsecticides seront présentés et leurs avantages et inconvénients seront discutés.

\section{INTRODUCTION}

Wherever tobacco is collected, stored or processed, the danger of endemic insect infestation is constantly present. The estimated annual loss to the tobacco industry due to the worldwide occurrence of this type of pest is $0.7 \%-1$ $\%$ of the various tobacco varieties held in storage for the manufacture of tobacco products $(7,86)$. In extreme cases, the damage incurred can affect as much as $6 \%$ of the stored material. The resulting financial loss to the tobacco industry amounts to some US\$ 300 million - a huge sum in view of the efforts mounted to protect stored tobacco products. Two insect species in particular should be mentioned in this context, the cigarette beetle (Lasioderma serricome) and the tobacco moth (Ephestia elutella), which, as the two major pests responsible for damage tobacco during storage and processing, play a significant role $(7,61,86)$.

The damage caused by the feeding activities of cigarette beetle larvae poses the greatest threat here. These not only attack every type of dried tobacco but also the entire range of commercial products manufactured from tobacco, such as cigarettes, cigars, chewing tobacco and snuff (27). The worldwide distribution of this insect and its resilience to unfavourable environmental conditions and resistance against the toxic effects of many insecticides mean that attempts to combat it meet in most cases with only limited success ( 7 ). The danger that a tobacco warehouse recently cleared of pests may be re-infested by the next consignment of fresh goods or through inadequate hygienic measures is ever-present.

Indications have been found in the tombs of Tut-ankhamun and Ramses II that the cigarette beetle was known as a pest of stored goods more than 3,000 years ago (86). Fabricius produced the first scientific account of the species in 1792. However, the first reports of damage to tobacco attributed to Lasioderma serricome only appeared from 1848 onwards (3).

The discovery that the tobacco moth Ephestia elutella is also a major pest in stored tobacco can be dated to 1915 
(4). The main distribution of the moth is in the temperate zone of the Northern Hemisphere. Here, too, the real cause of damage is the larva. Adult insects take in no food (27). In contrast to the cigarette beetle, the tobacco moth does not attack finished tobacco products. The larvae prefer Virginia and Orient tobaccos with a high sugar content which are low in nicotine. In addition, there is a whole range of further insects which can be found occasionally in tobacco warehouses, e. g. the larger tobacco beetle (Catorama tabact), the fungus eating hairy fungus beetle (Typhaea stercorea), or the dried foodstuff eating drugstore beetle (Stegobium paniceum), but these are of merely secondary and minor importance as tobacco pests (86).

\section{PROTECTIVE MEASURES FOR STORED GOODS AND INFESTATION CONTROL}

Modern methods for combatting the two major pests Lasioderma serricorne and Ephestia elutella are based on complementary measures to prevent infestation in the first place, and to monitor and reduce the insect populations. This so-called "integrated pest management programme" has as its first line of defence the hygienic procedures which must be observed, i. e. the immediate and thorough removal of tobacco waste and tobacco dust, the construction of mechanical barriers to prevent or hinder insects from entering through open windows or doors, or separate storage for newly arrived shipments of tobacco and storing tobacco in different rooms according to variety and age, to mention only a few control measures. All these are intended to prevent or at least significantly retard the spread of these insect pests (86).

\subsection{Monitoring infestation by means of pheromone traps}

As an additional flanking measure, this preventive programme to reduce infestation is accompanied by regular monitoring of the insect population, which enables the reproductive cycles of the two pests to be quickly and accurately determined. The tobacco industry these days favours the pheromone trap. The various models of light traps are as a nule less sensitive and are today only rarely used (88). Pheromone traps for tobacco moths allow 6.4 - 7 times as many moths to be caught as with light or adhesive traps $(13,33)$. Even better trapping rates can be achieved with the cigarette beetle in traps on a pheromone basis. Compared with conventional trapping methods, the use of pheromones yields a 10-15 times higher success rate (37). The pheromones used in these beetle traps are volatile organic signalling substances which in nature are released by the female cigarette beetle in order to attract and sexually stimulate males. The most effective of these substances has proved to be $(4 \mathrm{~S}, 6 \mathrm{~S}, 7 \mathrm{~S})$-serricornin, which forms the main component in the pheromone mixtures used to monitor the beetle population, and is available commercially. The female tobacco moth similarly secretes a sexual pheromone, known as ( $Z, E)$ 9, 12-tetradecadien-1-ol acetate or ZETA. Here, too, the signalling effect of the substance assists the male to locate a sexual partner or stimulates the males to mate. Pheromone traps of various patterns based on the signal effect of ZETA have been built, but have not up to now been used to the same extent in the tobacco industry as pheromone traps for cigarette beetles. Pheromone traps for Ephestia elutella are mainly used in raw tobacco storage plants and in transit areas (86).

The use of pheromone preparations in combatting storage pests of tobacco has proved to have a number of advantages for the tobacco industry. Due to the specific effect of the signal substance on the male beetles and moths, only tobacco pests are attracted. Toxic residues which can frequently be deteeted after treatment with conventional insecticides are virtually excluded by the use of pheromones. Pheromones are readily biodegradable. To date, no development of resistance to these compounds has been observed (53). Through the ecologically beneficial use of pheromones to monitor the insect population, it is possible to detect any uncontrolled multiplication immediately and take appropriate steps to deal with it. The source of infection can be localized and isolated, and the use of conventional insecticides and fumigants can be kept to a minimum.

Efforts are being undertaken to improve the yield of pheromone traps to the point where they go beyond the. pure monitoring function. An interesting new variant is represented by .. the so-called pheromone-baited multi-surface trap (14). In this type of trap, additional adhesive-coated surfaces are arrayed concentrically around a fixed pheromone source. The pheromonebaited multi-surface trap enables 8.5 times the number of cigarette beetles to be caught as with the conventional pheromone trap (e.g. Lasiotrap). It remains to be seen whether it will prove successful in practical use in tobacco warehouses and gain acceptance. However, the pheromone traps used up to now only attract the male beetles. In order to permit truly effective control, future designs should include methods for decimating the population of females. The so-called bait compounds could play a key role here. In these traps attractants (male or female pheromones) or food sources are offered together with a poison (90). The particular advantage offered by baits is that they possess greater attractiveness for the insects than other sources in their environment, and in addition stimulate oviposition. In contrast to conventional insecticides, they are not applied on an entire area, but can be used locally without causing any 
contamination to surrounding areas. It remains to be seen whether these new methods enable effective control of Lasioderma serricome and Ephestia elutella.

\subsection{Physical methods of control}

Among the preventive measures which can contribute to the effective control of insect populations are certain physical methods, some of which are already used during tobacco processing $(61,86,99)$.

The different stages in the life-cycle of both the cigarette beetle and the tobacco moth are susceptible to effects from high and low temperatures, and can either be killed or their development considerably retarded by these means. Setting the temperature at $60^{\circ} \mathrm{C}$ for five minutes during the reconditioning of dried tobacco suffices to destroy $75 \%-99 \%$ of all stages of the insects (86). Cold treatment of dried tobacco is also employed $(50,80)$. It has been demonstrated experimentally that the various stages of Lasioderma serricome and Ephestia elutella have differing degrees of susceptibility in this respect. The larval stage of the tobacco moth is least susceptible to cold, being able to survive temperatures as low as $-18^{\circ} \mathrm{C}$ for several days. One procedure frequently used is to freeze raw tobacco at less than $-20^{\circ} \mathrm{C}$ for more than five days. Storing tobacco and tobacco products in cold conditions at $4^{\circ} \mathrm{C}$ for more than 90 days can also lead to a significant reduction of infestation (86). The advantage of extermination by cold at temperatures between $-20^{\circ} \mathrm{C}$ and $-30^{\circ} \mathrm{C}$ is that the procedure is absolutely non-toxic and environmentally friendly. The disadvantage lies in the long period that the tobacco must remain in the cold chamber to guarantee virtually complete extermination of the insects. Due to the limited size of a cold chamber, only a certain contingent of tobacco can be cold-treated at any one time, so that treating the entire contents of a storage plant is energy- and time-consuming.

\subsection{Insecticides and fumigants}

If the preventive measures taken to ensure proper hygienic conditions when storing tobacco prove inadequate, the stored material can be seriously threatened. It then becomes necessary to take swift and effective countermeasures using insecticides or fumigants. Widespread use is made of storage protectants on the basis of dichlorvos (DDVP) or pyrethrins, which can be used either alone or in combination. These are usually applied as space sprays or as aerosols, but are occasionally also sprayed onto surfaces $(7,86)$.

The first insecticides to be used for protecting stored tobacco were pyrethrins. This is the collective name for naturally insecticidal substances extracted from
Chrysanthemum spp, whose lethal effect on the cigarette beetle and tobacco moth can be increased by adding a synergist such as piperonyl butoxide. Pyrethrins are still in use to this day in the tobacco industry all over the world due to their outstanding efficacy against storage pests and their relative harmlessness to mammals $(7)$. The active principle involved in their effect is based on the voltage-dependent blocking of sodium ion channels within the cell membranes of the insect neurons (44). A similar level of efficacy against pests of stored tobacco was achieved by DDVP, first introduced in 1955 - 1958. Due to its high vapour pressure, DDVP is toxic to the respiratory tract, but it is also effective as a contact poison and a stomach insecticide (68). DDVP was employed against tobacco pests in the USA from 1960 to 1986. The US tobacco industry then discontinued its use in insecticide preparations due to its relatively high toxicity for humans and animals and the resulting potential risks.

An important role in the protection of stored tobacco is still played by metallic phosphorus compounds which release hydrogen phosphide. These fumigants, which have been used in the tobacco area since 1959 in the form of aluminium and magnesium phosphide, can penetrate deep into the tobacco bales in their volatile form as phosphine and, properly used, quickly lead to a $100 \%$ certain extermination of all stages of the insects. Compounds containing $\mathrm{PH}_{3}$ have a reductive effect on $\mathrm{S}-\mathrm{S}$ bonds which are partly responsible for the formation of the tertiary structure in many proteins, and can also act with the free $\mathrm{SH}$ groups in the active catalytic centres of enzymes (77). Important advantages possessed by this class of substances in comparison with other storage protectants are low cost, less residues, and absolutely no impairment of tobacco quality after fumigation $(16,77)$. Magnesium-based phosphide compounds are approved in Germany for use against the cigarette beetle and tobacco moth in raw tobaccos (9). The disadvantage of this method, however, lies in the rather long treatment period of several days. The fumigated tobacco storerooms can only be entered after this period has elapsed. Furthermore, the high toxicity of hydrogen phosphide to humans and the environment requires elaborate safety procedures during and after the release of the gas, and the use of specially trained personnel. Consequently, the authorities and government organizations find themselves under increased pressure from environmental groups who would like to see the use of metallic phosphorus compounds prohibited or at least severely curtailed (77). There has further been growing evidence over the past few years to suggest that cigarette beetles are becoming increasingly resistant to fumigants containing $\mathrm{PH}_{3}(78,101)$. In the past, phosphine resistance in storage pests has proved to be specific to the compound, not extending to related 
hydrides. Since resistant insects absorb only small quantities of phosphine compared with susceptible strains, active exclusion mechanisms apparently play an important role here (76). The uptake and entry of hydrogen phosphide into the cell is already delayed by a membrane component. At the same time, a slow process of oxidation to hypophosphite has been observed. In contrast, phosphine transport from the tracheoles into the surrounding tissue, where it then very quickly leads to disruption of redox systems and the release of free radicals, remains unchanged in susceptible insects.

A possible future substitute is represented by inert gases such as carbon dioxide or nitrogen $(86,90,99)$. It is well known that an atmosphere of $60 \% \mathrm{CO}_{2}$ with less than 1 $\%$ oxygen will destroy tobacco pests. However, the period which must be allowed for this to work effectively is rather long (ca. 14 days). There is also the problem that the carbon dioxide escapes into the atmosphere when the storage facility is subsequently ventilated. This should be avoided if possible, since the increase in atmospheric $\mathrm{CO}_{2}$ is regarded as being responsible for the greenhouse effect (86). Release of $\mathrm{CO}_{2}$ into the environment can be prevented however by equipment for the recovery of carbon dioxide. The use of neutral gases in the form of carbon dioxide is permitted in Germany to protect stored tobacco in so-called Pex and Carvex pressure chambers (9). However, this method is seldom used by the tobacco industry today (86). The treatment period can be considerably shortened by this method, but the small capacity of the chambers only allows treatment of small quantities of tobacco at a time. In addition, the treatment of finished tobacco products by the Pex pressure method, cigarettes for instance, could lead to damaging the packets. Inert gas atmospheres containing $60 \% \mathrm{CO}_{2}$ are generally just as toxic for humans as fumigants containing hydrogen phosphides. However, the level of safety is much higher during fumigation and degasing with neutral gases; no residues of any kind are to be expected, and any threat to the surrounding area of the fumigated building can be virtually excluded (90).

The use of nitrogen for protecting stored goods has up to now been restricted in Germany to combatting pests of cereals stored in gas- tight silo cells. Compared with carbon dioxide, fumigation by means of $\mathrm{N}_{2}$ needs even longer treatment periods of 6 to 10 weeks (9).

The tobacco industry has shown particular interest in recent years in storage protectants based on methoprene $(20,22)$. This is a hormonelike agent which induces changes in the insect's metamorphosis cycle. Methoprene works as an analogue of the insect's juvenile hormone farnesol, preventing the larva's development into the imago stage. Larvae which come into contact with methoprene-treated tobacco or take up the agent continue their normal development, but are unable to complete the metamorphosis from the pupal stage into adulthood and die. By suppressing development into reproductively viable cigarette beetles and tobacco moths, the life cycle of the pests is interrupted, thus providing effective protection of the stored tobacco 7 , 20,86 ). Methoprene has been used by the US tobacco industry for pest control in tobacco storage since the end of the seventies. The experience gained here shows that a concentration of $5 \mathrm{ppm}$ is sufficient to guarantee effective control of cigarette beetles and tobacco moths and long-term protection of stored tobacco for more than two years. At these concentrations, there is also no negative effect of any kind on the aroma and taste of finished products made from this tobacco $(7,20)$.

Formulations containing methoprene such as Kabat and Dianex have meanwhile been approved for use for the protection of stored tobacco in many countries all over the world. Intensive efforts have been going on for some years now to obtain such approval in Germany. Up to now, however, the Biologische Bundesanstalt für Landund Forstwirtschaft <Federal Office for Agricultural and Forestry Biology $>$ has not yet given permission to register these commercially produced methoprene-based products for pest control in stored tobacco. Due to the excellent results achieved with methoprene in destroying insects even at low concentrations and its minimal toxicity for humans and the environment, this insect growth regulator would seem to be eminently suitable for the control of the cigarette beetle and the tobacco moth. It is however a disadvantage that the death of the insects only occurs after weeks or even months have passed, at the point when the larvae, which continue to feed on tobacco during this time, pupate (27). First reports have also begun coming in concerning the development of methoprene resistance in Drosopbila melanogaster strains fed under laboratory conditions on a diet containing methoprene together with a mutagenic agent (98).

\section{Biological pesticides as alternative storage protectants}

When we attempt to weigh the pros and cons of the insecticides used in tobacco storage, it becomes clear that, with the exception of methoprene, every active substance used for this purpose entails a greater or lesser toxic potential risk to humans and the environment (cf Tab 1). During the last few years, public debate on pesticide use has revolved more and more around the criteria of low toxicity for humans and the ecology and a continuing reduction of the quantities applied (53). This has led to a situation where in Europe, the USA and many other countries a determined effort is being made to replace 


\begin{tabular}{lc|c}
\hline \multicolumn{1}{c|}{ Insecticide } & Application, Organism & $\mathrm{LD}_{\mathbf{5 0}}\left[\mathrm{mg} \times \mathrm{kg}^{-\mathrm{t}}\right]$ \\
\hline $\begin{array}{l}\text { Pyrethrins } \\
\text { Dichlorvos }\end{array}$ & oral, rat & $584-900$ \\
Methoprene & oral, rat & $56-80$ \\
Neem-extract (Azadirachtin) & oral, rat & 34.600 \\
B. thuringiensis (Dipel) & oral, rat & $>5.000$ \\
B. thuringiensis (Thuringiensin) & oral, mouse & 10.000 \\
\hline
\end{tabular}

conventional synthetic insecticides increasingly by highly effective and ecologically beneficial biological pesticides $(44,56)$. A further important factor which lends urgency to the search for new classes of insecticidal substances is, as mentioned above, the development of resistance already observed in tobacco pests to many of the pesticides hitherto used in storage protection...The properties required of such compounds would be the highest possible degree of specificity against the insect pests occurring in tobacco storage, little or no ecologically harmful effects or effects on humans and other organisms from the active substance involved or its derivates, biodegradability into non-toxic metabolites, no alteration to the aroma and taste of the tobacco due to possible residues which may occur, and a competitive price level.

Intensive research into natural substances and biological organisms over recent years has demonstrated that they may prove a good source of bioinsecticides, and that several of them indeed have nothing to fear from a comparison with conventional synthetic pesticides (28, $29,30,42$ ).

In the following, I would like to present a number of promising bioinsecticides which could be an alternative to the protectants used up to now, and will discuss details of their possible use for the control of the cigarette beetle and the tobacco moth.

\subsection{Endotoxins from Bacillus thuringiensis (B. t.)}

The endotoxins isolated from Bacillus thuringiensis are among the most interesting bioinsecticides known at the moment. These are peptides with a highly specific insecticidal effect, which are found as visible crystalline deposits in the interior of $B . t$ species. Surprisingly enough, the discovery of this bacterium and its first use as an insecticide can be dated back to the first half of this century. The first preparations with this bacterium intended for commercial use were tested in France at the end of the thirties (23). 'The higher costs of manufacture compared with the synthetic insecticides in use at that time and the selective effect of Bacillus thuringiensis. toxins combined to prevent an early use of these biopesticides. Today, this is the most often used microbial insecticide, with a market share of $90 \%$ and an annual turnover in excess of US $\$ 125$ millions $(26,91)$. Serious commercial use of $B$. t. preparations began in the fifties. They were employed as biological pesticides for the control of caterpillars in forestry and in agriculture (85). Until well into the seventies, only the insecticidal effect of Bacillus thuringiensis on the larvae of the lepidoptera was known. This type of insecticide is synthesized among others from the variety B.t. kurstaki and is available commencially as Dipel, Biobit, Thuricide or Delfin (10). In 1977, a new variety, B.t. israelensis, which was toxic to the larvae of diptera, was isolated by GOLDBERG and MARGALIT (35). These substances, too, are marketed as Vectobac (24). In 1983, KRIEG et al. discovered a new strain which had insecticidal effects on leaf beetle larvae (54). This new variety was named B.t. tenebrionis and is used under the name Trident or Novodor, mainly to control the Colorado beetle (Leptinotarsa decemlineata) $(10,17)$. In the meantime, formulations based on Bacillus thuringiensis are even in use in tobaccocultivation in the USA for the control of 
many tobacco pests (e. g. Heliotbis virescens, Manduca sexta) with good results (71). In Germany, Bacillus thuringiensis-based insecticides are not used on tobacco fields, but are approved for the control of many insect pests in arable farming, market gardening and vineyards as well as in forestry (10).

The toxic effect of this Gram-positive ground-dwelling bacterium on insect pests derives from its ability to synthesize special proteins known as endotoxins, which are deposited in the interior of the bacterial cell as crystalline inclusions during sporulation (38). These protein crystals have been found to account for more than $30 \%$ of the dry weight of the spores. When ingested by certain insects, they dissolve in the digestive tract of the pests and cause irreversible damage to the cells of the gut epithelia. This results in complete destruction of the digestive tract over the following 24 to 48 hours, leading to the death of the insect $(23,24,38)$. The protein crystals contained in Bacillus thuringiensis possess a highly specific insecticidal activity which can be employed with good effeet against the larvae and imago stages of lepidoptera, diptera and coleoptera. In the meantime, additional endotoxins have been isolated which can be used to combat animal ectoparasites, endoparasitic protozoa and also nematodes $(1,24,65)$. The numerous subspecies of $B . t$. can contain crystal proteins of varying composition. Merely the examination of the natural microflora of stored tobacco led to the isolation of a total of 78 strains of B.t., which could be identified and characterized according to their differing parasporal crystal morphology (48).

Most of the protein crystals are plasmid-coded protoxins with a moleculan weight of approx. 135,000:(2,38). If , for instance, the protoxins of variety B.t. kurstaki enter the digestive tract of the lepidoptera larvae, the crystals dissolve in the alkaline medium of the gut and cleave into the effectively toxic fragments which have a molecular weight of $60,000-70,000$, due to the protease effect of the insect's digestive enzymes (2). For endotoxins from $B . t$. tenebrionis effective against coleoptera, in contrast, the optimum $\mathrm{pH}(<4)$ is in the acid range (25). However, the B.t. tenebrionis protein is also soluble at high $\mathrm{pH}(>$ 10) (1). The activated toxins interact with the epithelial cells of the insect's gut if the appropriate receptors are present in the cell membranes (93). Apart from their specific effect on lepidoptera, diptera or coleoptera, most of the endotoxins possess, as far as is known, five conservative amino acid domains which presumably contain the components toxic to insects belonging to the orders described above $(2,38,59)$. In addition, part of the toxiprotein is a highly variable amino acid sequence which is assumed to be involved in binding the protein to the epithelial cells of the insect's gut. This explains the high insect specificity of the various endotoxin classes (2, $25,59)$. These macromolecules only have a toxic effect on organisms in which the proteins are soluble in the gut, and which show specific structures for the binding of a special endotoxin.

When endotoxins are bound to or directly incorporated into the membrane of the gut cells, small non-specific pores of $0.5-1 \mathrm{~nm}$ size are induced, leading to dissipation of the transport systems. Due to a rapid outflow of smaller molecules followed by an uncontrolled inflow of ions and water, the osmotic equilibrium of the cell is seriously disturbed. The cells swell up and lyse, thus destroying the insect's gut $(23,38)$. As the endotoxins develop their insecticidal effect as a feeding poison rather than by contact, other insect pests such as aphids or the

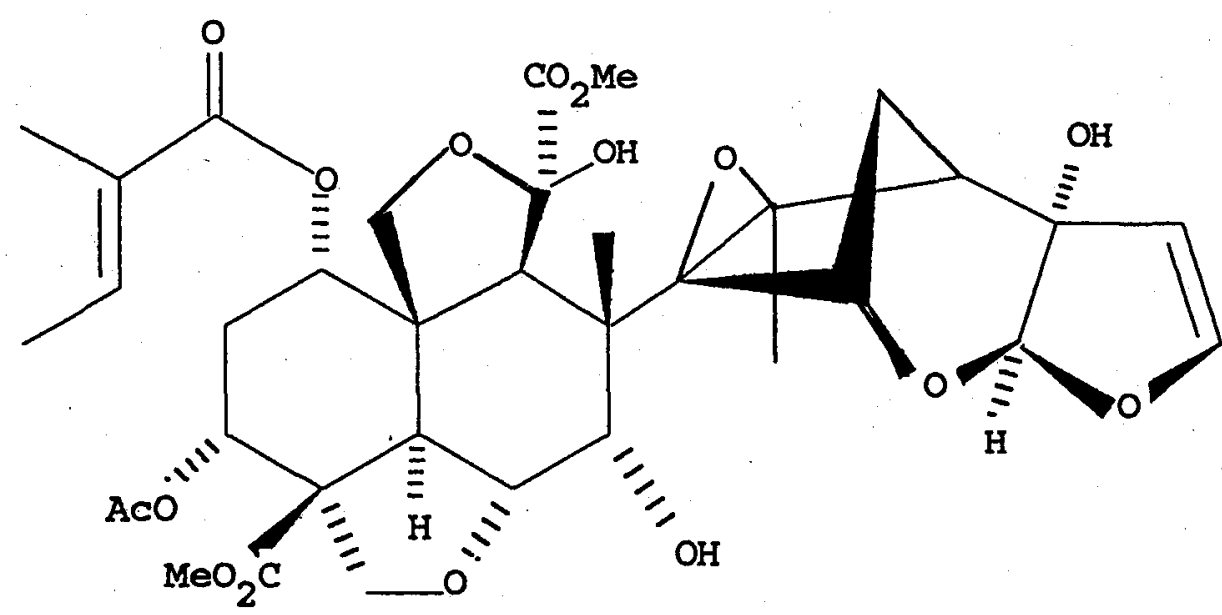

Figure 1.

Chemical structure of azadirachtin, an active ingredlent from the seeds of the neem tree Azadirachta indica. 
whitefly remain unharmed. The same is true for other invertebrates or vertebrates, which are not affected by the activity of crystal proteins in any way.

In general, more than one specific crystal protein is synthesized from the varieties of Bacillus thuringiensis. The majority of B.t. spores contain a mixture of protein crystals from the products of closely related genes $(2,83)$. Certain B.t. varieties, such as Bacillus thuringiensis israelensis also produce so-called exotoxins, which are however not found as crystalline inclusions in the spore bodies, but are released externally. As in contrast to endotoxins, B-exotoxin (Thuringiensin) has a toxic effect on vertebrates (see Table 1), the use of Thuringiensin in plant protection/storage protection appears to be far more problematic than the use of endotoxins (49). Since endotoxins are not known to have any toxic, carcinogenic, mutagenic or teratogenic effects on mammals, vertebrates or on the environment $(19,23,56)$, the EPA saw absolutely no reason to set maximum residue limits for the use of endotoxins (23). The various insecticide-producing strains of Bacillus thuringiensis, especially the varieties kurstaki, israelensis and tenebrionis, are easy to culture in large quantities in a number of simple and inexpensive media. Culture is usually carried out in large tanks. At the end of the growth period the cells break up, releasing large amounts of spores and crystal proteins into the culture medium (32). These spores and crystal proteins form the active component of the B.t. preparations available on the market, which are applied on crops for pest control. However, the instability of endotoxins causes specific problems when used on field crops. The fact that the active substances decompose within one to four days after application of the preparation often makes it necessary to repeat the treatment during a vegetation period $(32,94)$. It should be borne in mind that these substances are proteins which, as high-energy substrates, are a nutritive source for other organisms and are thus subject to a natural rate of decomposition. Another major factor which impairs the persistence of the crystal proteins is sunlight (72). Therefore considerable efforts have been made in recent years to transfer the plasmid-coded endotoxin genes of the bacterium into tobacco and other crops to enable them to synthesize the endotoxins themselves. It proved possible to express these transferred genes in the plant and, after uptake of plant material by the larvae, this led to the extermination of the pests $(6,30,94,97)$. By this procedure, endotoxin enrichment of $3-5 \%$ of soluble total protein was achieved (64). This opens up a wide range of new options for combatting tobacco pests. It is conceivable that in the near future tobacco plants capable of protecting themselves by synthesizing biological pesticides such as endotoxins will be grown, so that treatment of the plant with pesticides will no longer be

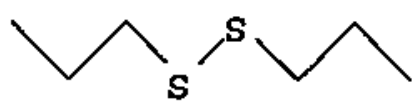

Di-n-propyl disulphide

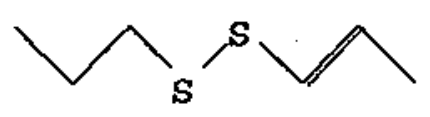

n-Propyl-trans-1-propenyl disulphide

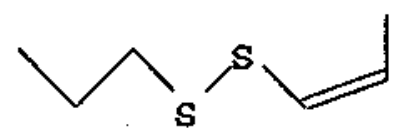

n-Propyl-cis-1-propenyl disulphide

\section{Figure 2.}

Chemical structures of the principal volatlle organosulphur compounds isolated from neem oll.

necessary. Here too, nature sets certain boundaries: if one and the same insecticide is constantly used, the insect pests are able to develop resistance which enables them to detoxify the active substance. This undesirable ability of the insects to adapt to the endotoxins of Bacillus thuringiensis has already been observed in laboratory tests with Heliothis virescens (26). A solution to the problem can be offered by a temporarily controlled expression of B.t. endotoxin genes in transgenic tobacco (97), or by incorporating chimeric genes into plants which produce a combination of endotoxins with differing effective specificity $(26,95)$. The development of resistance against the effect of the B.t. toxin should be considerably hampered by these measures.

The question arises whether the proteins from the various strains of Bacillus thuringiensis which have a toxic effect on insects could also be used for the protection of stored tobacco and tobacco products.

B. $t$. formulations derived from kurstaki and tenebrionis varieties are known to be effective in the control of the tobacco moth and the cigarette beetle. In USA, the use of Dipel has been recommended for some time to prevent damage through Ephestia elutella (71), while a method for the control of cigarette beetles using B.t. tenebrionis has 
been registered under Patent Specification No. EP 0448 220A1 since 1991 (21). Therefore, in view of their selective effect on beetle and moth, their above-mentioned low toxicity on other organisms, and since they are readily biodegradable, B.t. preparations are a very promising alternative to the conventional protectants for stored products. However, such a procedure would involve certain problems due precisely to this low persistence of the crystal proteins, which last only a few days when applied to field crops, so that repeated application of the B.t. products would be necessary for stored tobacco. Fortunately, endotoxins are much more stable on dried tobacco, and still exhibit sufficient insecticidal potential even three months after application (21). These biological preparations can be given further improved persistence characteristics by using crystal protein inclusions distributed by Mycogen Corporation. The production of these endotoxins which decompose slowly ( 7 to 10 days stable on field crops) is based on the principle of transferring endotoxin genes from Bacillus thuringiensis into the non-pathogenic bacterium Pseudomonas fluorescens $(1,32)$. Pseudomonas fluorescens cells which synthesize endotoxins themselves as a result of this effect are killed before they release endotoxins, and their membranes used for the protection of the sensitive protein crystals $(24,32,72)$. At present, no published data are available which illustrate an adequate stability of endotoxins during the processing of raw tobacco.

Another problem involved in the protection of stored tobacco using B. $t$. arises from the fact that both Dipel and Novodor would have to be applied simultaneously in order to control both the cigarette beetle and the tobacco moth. The use of new B.t. varieties which synthesize larvicidal endotoxins against species of coleoptera and lepidoptera possibly represents a more elegant solution $(15,65,92)$. In this connection, Foil - a product which has been on sale for some time - should be mentioned here. The active ingredient of this product is a transgenic $B$. $t$. strain with two different plasmids, one of which causes the specificity to coleoptera while the other is coding for endotoxins against lepidoptera (23). Such a combined preparation might be a useful means to simultaneously achieve successful control of the tobacco moth and the cigarette beetle.

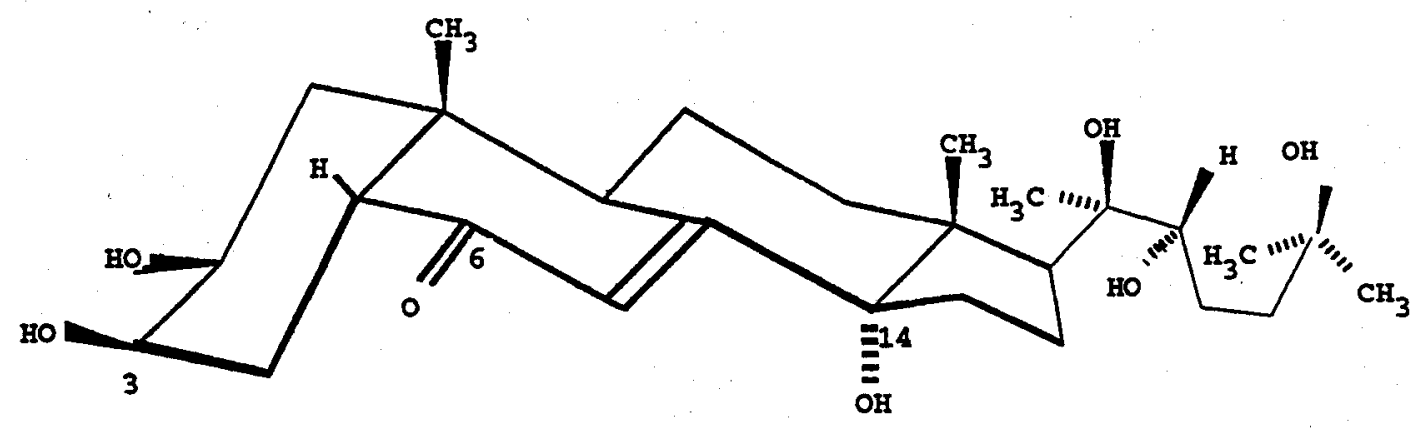

Azadirachtin skeleton: Deөsterified (1,3-dideacylated)

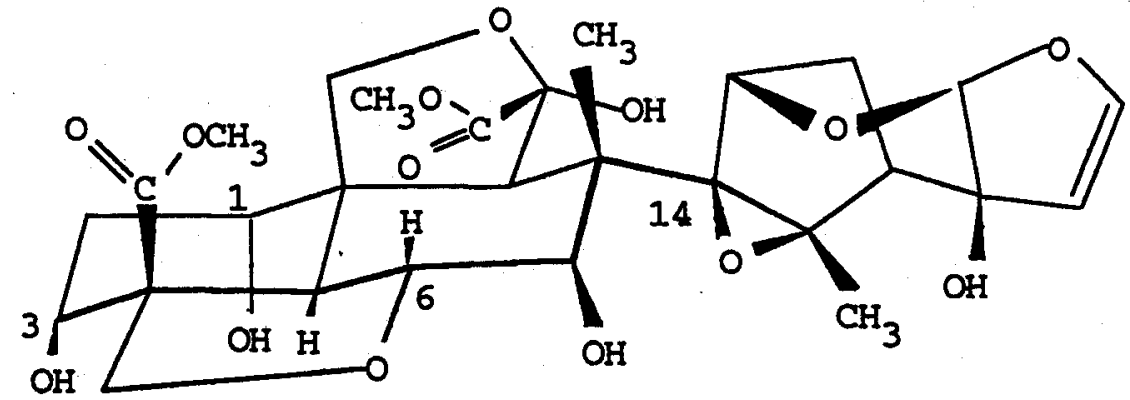

Ecdysterone (20-hydroxyecdysone)

Figure 3.

Stereostructural relatioship between azadirachtin and ecdysterone. For maximum insecticidal activity of azadirachtin free hydroxyl groups are essential. 


\subsection{Neem preparations and their possible uses}

There is no doubt that the extracts and oils of the neem tree (Azadirachta indica) take pride of place among the known natural substances with insecticidal effects. The origins of the neem tree are to be found on the Indian subcontinent. Today it is also cultivated in South-East Asia, Australia, Central and South America as well as in some parts of USA. This plant contains highly effective insecticidal substances which at the same time have little or no toxic effect on the environment. The seeds of the olive-like fruit, in particular, yield numerous compounds with insecticidal properties (44). Complex triterpenoid compounds, called limonoids, have been found to be the biologically most active constituents of the neem seeds. They include the tetranortriterpenoid azadirachtin, a highly insecticidal compound, which is found at concentrations of $1.5-6.2 \mathrm{~g} / \mathrm{kg}$ neem seeds (63) (Figure 1). Azadirachtins are a class of compounds of which more than 16 isomeric structures have been identified. The predominant tetranortriterpenoid is azadirachtin A (75). These bioactive substances are generally obtained from the neem seeds in the form of alcoholic extracts (18).

Another product derived from the seeds is an oil with a garlic-like odour and a high content of sulphur compounds $(43,57)$. To date, 22 volatile organosulphur compounds have been identified in neem oil. As has been demonstrated, the major volatile constituents are $\mathrm{di}$ n-propyl disulphide, n-propyl-trans -1-propenyl disulphide and n-propyl-cis-1-propenyl disulphide (Figure 2). In biotests, di-n-propyl disulphide has also been found to have larvicidal properties when used against the larvae of Heliothis virescens $\left(\mathrm{LC}_{50}: 1,000 \mathrm{ppm}\right)(5)$. The repellent effect of the neem tree, as exemplified by the desert locust, may be partly due to the constituents of the plant's leaves and seeds which contain sulphur.

But the effective principle which, in fact, makes the neem seed constituents, especially azadirachtins, potentially so valuable as plant protectants is the impairment and inhibition of insect metamorphosis at extremely low doses, rather than their antifeeding properties $(18,44$, 65). Azadirachtins do not kill the insect immediately. However, if taken up by an insect, they alter growth and development. Thus, a large number of insect larvae treated with azadirachtin do not undergo normal moulting and die before reaching reproductive maturity or develop into sterile adult insects (89). Azadirachtins are similar in structure to the insect hormone ecdysone which is essential for moulting (Figure 3). It is known that azadirachtin, as an ecdysteroid analogue, blocks the ecdysone receptors in the insect's brain, thereby triggering disturbances of the hormonal balance. In addition, impairment of other organic functions has been observed. Neem constituents inhibit the biosynthesis of chitin, which forms an integral part of the insect's exoskeleton, or decrease gut motility $(34,43,44,65)$. This broad range of different bioeffects on insect pests clearly shows why more than 300 insect species including lepidoptera, coleoptera and nematodes have been found to be susceptible to the constituents of neem seeds (36, 79). A comparison of the insecticidal potential of various natural substances such as pyrethrin, kryocide, rotenone, ryania, sabadilla and azadirachins with respect to their effect on Heliothis virescens shows that the application of neem compounds leads to mortality rates in the larval population of the tobacco budworm which are among the highest achieved by any insecticide (100). In addition, due to the numerous interactions of neem compounds with the insect organism, there is far less likelihood of a resistance developing to the active substances. Thus, no resistance to neem insecticides has been reported to date for the known insect pests of cultivated plants, even though the neem tree has been used for centuries by the Indian population to protect field crops and stored foodstuffs, as well as for medicinal purposes in the treatment of all manner of ailments and diseases $(44,46$, 84).

If wheat, barley, rice, sugar-cane, tomatoes or tobacco are sprayed with water containing neem extract, the plants are systemically protected against pests for several weeks $(46,63)$. Experiments have also been carried out using neem oil to inhibit sucker growth in tobacco cultivation. Emulsions containing $30 \%$ neem oil proved to be very effective in inhibiting sucker growth $(8,73)$, while at the same time neither crop yield nor tobacco quality were found to be impaired. As shown by studies of MURTHY and NAGARAJAN using Bidi-tobaccos, neem oil preparations can also be used for controlling parasitic plants, such as Orobancbe cernua (55).

Neem preparations play a major role in storage protection. Neem leaves are strewn around in many Indian homes to discourage storage pests and parasites. Meanwhile, neem products are also known to protect maize, peas, millet, rice and also grain against pest infestation after harvesting $(60,89)$. However, neem preparations are rarely used by industry in storage protection. This may be partly attributable to the organoleptic properties of the neem formulations which are commercially available currently, and to their varying degree of efficacy against storage pests $(5,90)$. As can already be seen from the numerous descriptions of possible uses of neem oils and extracts, the use of neembased plant or storage protectants is unlikely to involve any risks or problems for more highly developed organisms or the environment. Animal experiments have shown an $\mathrm{LD}_{50}$ of more than $5 \mathrm{~g} / \mathrm{kg}$ in rats after oral uptake of a solution containing $3 \%$ azadirachtin (Tab 1). Neem products did not show mutagenic activity in the Ames Test $(44,81)$. In view of the relatively low toxicity 
of neem constituents for vertebrates, the US Environmental Protection Agency EPA decided to register Margosan-O (W $R$ Grace \& $\mathrm{Co}$ ) as the first neem-based insecticide in the USA in 1989. In 1993, Azatin (Agri Dyne Technologies Inc) containing 3\% azadirachtin was registered for the first time for use on food plants. In Germany, too, attempts have meanwhile been made by 'Trifolio-M GmbH to obtain approval for neem-based pesticides. Neem Azal-T/S, a product containing azadirachtin $A$ at a concentration of $1 \%$, was developed by this company to combat pests in fruit and potato growing and in forestry (52).

Attempts have recently been made to produce azadirachtin, the major active substance of neem, by preparing Azadirachta indica cell cultures (96). However; as the yield of neem constituents in the callus culture is still too low, the industrial use of this method may not be realized in the near future.

In view of the remarkable properties of neem extracts and the fact that they appear to involve no toxicological risk to man and the environment, the importance of tests to establish the suitability of these biological insecticides for the control of cigarette beetles and tobacco moths is undeniable. In this context, the first studies - carried out by RIEMENSBERGER - have now been concluded and documented in the form of a thesis (84).

Tests of neem extracts, neem oils and extracts of Melia volkensii, a relative of the neem tree, to determine their efficacy on the larval stages of the two major pests of stored tobacco revealed a high insecticidal activity of the neem extracts containing azadirachtin. A comparison with methoprene, used as a storage protectant in some countries, clearly shows that the neem extract has a lethal effect on the larvae of the tobacco moth at lower dosage and kills the larval stages of both the cigarette beetle and the tobacco moth more rapidly than the juvenile hormone analogue methoprene. In contrast to methoprene, application of neem extracts prevents the insect from developing through further larval stages (84).

In view of these results, there is reason to believe that the highly effective insecticidal properties of the neem tree constituents can also be exploited in the protection of stored tobacco and tobacco products. However, a major problem remains, namely the odour components typical of neem extracts, which thus far have made their use in the storage protection of tobacco appear doubtful.

In field studies by JOSHI et al., application of neem seed kernel suspensions on Virginia tobacco at concentrations of $0.5 \%, 0.75 \%$ and $1 \%$ as protectant against Spodoptera litura did not show any adverse effects either on the yield or on the chemical or physical quality characteristics of the tobacco (47). However, in onganoleptic tests of neem-treated tobacco specimens, neem concentrations of $0.75 \%$ and $1 \%$ were found to alter the taste of the smoke. The addition of antioxidants to the insecticidal formulation might help to suppress the garlic-like odour of neem. Unfortunately, the mask of antioxidant substances may be removed during pyrolysis of the tobacco, so that the odour-intensive sulphur compounds of neem again become apparent. Complete removal of the sulphurous components from the neem extract would therefore be a better solution. Thus, Neem Azal-T/S is the first commercially available neem preparation in which these undesirable constituents have been successfully removed by means of a special patented extraction method, resulting in a product which is for the most part odour-free. Future studies should attempt to determine whether such a formulation, after modification for special use in storage protection, is also suited for the control of tobacco pests.

\subsection{Possible uses of entomopathogenic viruses in storage protection}

The use of entomopathogenic viruses, such as the family of the Baculoviridae, has also met with increasing interest as an alternative to conventional pesticides $(23,39)$. Compared with other biological and synthetic plant protectants, these entomopathogens often have the advantage of high selectivity and specificity, since they generally infect only one host species (31). Viruses which have insects as hosts are found in numerous virus families. With the exception of baculoviruses, however, many of the other families are known to include viruses which may attack vertebrates or even mammals, including humans (58).

Therefore I would like to confine myself in the following to the description and characterization of this special group of viruses, particularly since the entomopathogenic properties of these species have been most thoroughly studied and may possibly have a role to play in future storage protection. The baculoviruses are double-stranded DNA viruses which are pathogenic for certain arthropods (e. g. larvae of lepidoptera, coleoptera etc). According to their structure, they fall into two genera, namely the Nucleopolyhedroviruses (NPV) and Granuloviruses (GV) $(12,58)$. Baculoviruses which are already used in pest control belong to the Nucleopolyhedroviruses (23). Infection by baculoviruses usually occurs orally. The process of infection begins after uptake with the dissolution of the protective protein coat, the polyhedron. Due to the strongly alkaline $\mathrm{pH}$ of the insect's midgut, nucleocapsids (virions) are released and taken up by the epithelial cells of the gut and transported to the nucleus. During the following replication of the viral genom a second viral-genotype is produced, a so-called budded vinus, which spreads from the site of the infection into the surrounding tissue. In 
the later stages of the infection cycle, the viral progeny is again enclosed by the polyhedron: after the death of the larva and decay of the carcass it is again released into the environment as NPV. The time required to kill an insect may vary from days to weeks, depending on the temperature, of the viral dosis taken up, the age of the insect, and the susceptibility of the host to the specific viral species (12). During this time the insect continues to take up food. Most baculoviruses are highly host-specific and generally confined to infesting only one specific insect species or closely related members. A small number of the NPV possess a somewhat lower host specificity enabling these types of viruses to be used for a broader range of applications. Thus baculoviruses, for example, which were originally isolated from Autographa californica (AcNPV) are capable of infecting more than 40 Lepidoptera species, including Heliothis virescens (39, 69). Baculovinuses have already been widely used in agriculture as well as in tobacco cultivation for the control of Heliothis and Spodoptera pests, particularly in Central and South America, India, Africa and South-East Asia (23). A point very much in their favour is that they do not involve any risk either to the environment, or to mammals and plants. In addition, there is no danger of residues after application, since they decompose easily outdoors as a natural part of biocoenosis $(31,39)$.

So far, the high host-specificity as well as the prolonged extermination time for the insects have proved an obstacle to the wider acceptance of these new insecticides. For some time now, efforts have therefore increasingly been directed towards selectively expanding the spectrum of baculovinus hosts or enhancing the insecticidal efficacy of the viruses $(12,39,67)$. Recombination of the baculovirus genom has already speeded up the time in which the insects are destroyed by $30 \%$ to $40 \%$. The introduction of a foreign gene which codes for a protein with insecticidal properties can improve efficacy. Positive results were also achieved for genetically modified viruses with an additional gene sequence for a regulatory protein which interferes with the physiological processes in insect metamorphosis (39). The range of hosts can be expanded by eliminating certain baculovirus genes. Thus, when using AcNPV after removal of the $\mathrm{p} 35$ gene, a higher susceptibility to infection and apoptosis was observed in insects which had so far not been susceptible to the virus (67).

In view of these remarkable properties of entomopathogenic viruses, particularly Baculoviridae, the question naturally arises as to whether these biological pesticides might not be suitable for controlling the two major pests of stored tobacco.

The use of these pesticides would presuppose that particular strains of viruses possess a specific pathogenic activity against Lasioderma serricome and Ephestia elutella; another prerequisite would be that a technique of application is used which affords inexpensive but effective control of the cigarette beetle and tobacco moth. Can we really assume that these two basic requirements for the use of entomopathogenic viruses in storage protection have already been fulfilled?

Early in the nineties, several articles were published by the University of Kentucky and USDA-ARS describing special strategies for Heliothis virescens control using baculoviruses in greenhouse and open field environments $(45,69,70)$. The method of budworm control which was applied in the earlier studies was based on the principle of autodissemination, a method which IGNOFFO had already proposed in 1978 as an alternative to common control strategies (41). In order to attract male $H$. virescens moths, JACKSON as well as NORDIN et al. used special pheromone traps in their studies: the insects were neither irmmobilized nor killed in these traps, but escaped after crossing a powder formulation consisting of AcNPV. During mating, the vinus- contaminated male transmits AcNPV powder to the female. If subsequent oviposition by the female takes place, the egg surface will be contaminated by the viruses. When the larvae emerge, they eat parts of the chorion. The amount of viruses ingested is sufficient to cause a fatal infection in the young insects (45).

In field tests, however, the results obtained with this new control strategy failed to meet expectations. Thus only $10 \%$ of the larvae which emerged were found to have a fatal infection with AcNPV under test conditions (45). According to the authors, this is attributable to physical factors (sensitivity of the baculoviruses to $\mathrm{pH}, \mathrm{UV}$ radiation). Another reason is that under natural conditions the free migration of the insects would also have to be taken into account.

Logically, the use of such a control strategy in a system which is largely enclosed - such as a tobacco storehouse could be expected to produce considerably higher mortality rates for the pests. The autodissemination technique would have the advantage that the pesticidal agent - the virus particle - would not have to be applied to the tobacco, but would be concentrated in small portions in special pheromone traps. Direct application of entomopathogenic viruses to stored tobacco would be unacceptable simply for economic reasons, since largescale virus production is still extremely material- and cost- intensive (31).

In contrast to the type of pheromone trap used so far for Lasioderma serricome and Ephestia elutella, which permits only monitoring of the male insect population, combined use of pheromone and virus particles might lead to a considerable disturbance of the whole life cycle of the two tobacco pests. However, no studies dealing with the autodissemination technique have appeared to date. This may very well be due to the fact that only scanty evidence of a pathogenic effect of viruses on the 
two pests of stored tobacco has hitherto been obtained. With regard to Ephestia elutella, only a weak pathogenicity was found in certain NPV strains $(40,51)$, whereas for the tobacco beetle, no positive study results have been published to date. Therefore, in view of the lack of sufficient data, the search for pathogenic virus strains to control Lasioderma serricome and Ephestia elutella should be intensified. Even at this stage it is possible to say that the entomopathogenic viruses will be of major importance in pest control. By using specific virus strains in combination with a modified pheromone trap, the enormous insecticidal potential of these nucleoproteins could also be exploited in the control of cigarette beetles and tobacco moths.

\section{CONCLUSIONS}

Endotoxins from Bacillus thuringiensis, the extracts of the neem tree or entomopathogenic viruses, such as the Baculoviridae, are clearly not the only alternatives which could play a key role in the protection of stored tobacco. It is highly probable that other natural substances or microorganisms which are suited for this purpose will be discovered in the next few years. For example, extracts from Azadirachta excelsa containing MarranginAzadirachtin compounds may already be such an alternative. Compared with the active substances of the neem tree, extracts from Azadiracbta excelsa showed a considerably stronger bioactivity on the larvae of the Mexican bean weevil (Epilachna varivestis) (87). It would be worth investigating whether this is not also true for the pests of stored tobacco. Further development of allelo-chemicals (e. g. pheromones, kairomones) could also help to appreciably improve trapping rates. The so-called "Kombidispenser" as developed by Trifolio $\mathrm{GmbH}$, which allow simultaneous trapping of male cigarette beetles and male tobacco moths, may be seen as a first step towards this aim, although this new type of trap still does not afford really effective control of Lasioderma serricorne and Ephestia elutella. A modified trap using pheromones in combination with the insecticidal properties of entomopathogenic vinuses, as in the autodissemination technique described above, could indeed lead to a breakthrough in this area. However, the NPV which are known to date exert only a weak pathogenic effect on $E$. elutella. The search for more host-specific infectious viruses for cigarette beetles and tobacco moths should therefore be intensified. In addition, it may perhaps be possible to increase the pathogenic efficacy for $E$. elutella through genetic modification of the virus genom. Such extensions or improvements of host specificity have been carried out successfully for other insect species in the past $(12,67$, 74). Finally, the idea of speeding up the extermination process and increasing the mortality rates of the insect larvae by transferring B.t. endotoxin or scorpion toxin genes into the virus genom is also worth considering (12, 82). Whereas, after virus infection, the expression of neurotoxin genes from scorpions or mites in the host contributed to a definite increase in pathogenicity, such an effect has not been observed so far with recombinant viruses which transferred a B.t. gene $(62,66,82)$.

Furthermore, the infectiosity and efficacy of specific entomopathogenic fungi in applications to the storage pests Plodia interpunctella and Ephestia kuebniella have already been documented (11); they could also play a future role in the control of the cigarette beetle and tobacco moth. Here too, the autodissemination technique would be a useful strategy for control. In contrast to entomopathogenic viruses, the use of entomopathogenic fungi would have the advantage that the intake of insecticidal particles is not necessary. Mere contact with the fungus spores is sufficient to infect the insect fatally.

In future, the range of possible uses of biological pesticides will certainly continue to expand in storage protection as well, and thereby complement or even entirely oust the traditional synthetic insecticides. However, this review does not claim to give an exhaustive survey or description of all bioinsecticides that may be used for the protection of stored tobacco in future. The organisms and natural substances referred to above merely represent some examples of the different strategies of biological pest control (entomopathogenic viruses, fungi and bacteria, natural substances). They do, however, typify some of the most promising developments, despite the fact that their potential as storage pesticides still requires careful examination. It should be pointed out that the use of even biological insecticides is only possible in the context of an integrated pest management system. Satisfactory protection of stored tobacco against pest infestation can only be guaranteed in future by a variety of complementary measures.

\section{REFERENCES}

1. Adams, L. F., Liu, C. L., Mac Intosh, S. C. and R. L. Starnes: Diversity and biological activity of Bacillus thuringiensis; in: Crop protection agents from nature, edited by L. G. Copping, SCI, U.K., 1996, pp. 360 - 388.

2. Aronson, A. J.: The two faces of Bacillus thurin. giensis: insecticidal proteins and postexponential survival; Mol. Microbiol. 7 (1993) 489 - 496.

3. Ashworth, J. R.: The biology of Lasioderma serricome; J. Stored Prod. Res. 29 (1993) 291 - 303.

4. Ashworth, J. R.: The biology of Ephestia elutella; J. Stored Prod. Res. 29 (1993) 199 - 205. 
5. Balandrin, M. F., Lee, S. M. and J. A. Klocke: Biologically active volatile organosulfur compounds from seeds of the neem tree, Azadirachta indica (Meliaceae); J. Agric. Food Chem. 36 (1988) 1048 - 1054.

6. Barton, K. A., Whiteley, H. R. and N.-S. Yang: Bacillus thuringiensis $\delta$-endotoxin expressed in transgenic Nicotiana tabacum provides resistance to lepidopteran insects; Plant Physiol. 85 (1987) 1103 1109.

7. Benezet, H.J.: Chemical control of pests in stored tobacco; 43rd Tobacco Chemists' Research Conference, October 2 - 5, 1989, Hyatt House Richmond, Virginia; Recent Adv. Tob. Sci. 15 (1989) 1 - 25.

8. Bhat, B. N., Rao, S. and S. Patil: Efficiency of certain suckerides on sucker growth in bidi tobacco; Tob. Res. 16 (1990) 115 - 117.

9. Biologische Bundesanstalt für Land- und Forstwirtschaft Bundesrepublik Deutschland: Pflanzenschutzmittelverzeichis Teil 5, Vorratsschutz, 1996.

10. Biologische Bundesanstalt für Land- und Forstwirtschaft: Pflanzenschutzmittelverzeichnis, Teil 1 - 4, 1996.

11. Bischoff, R. and C. Reichmuth: Virulence factors of entomopathogenic fungi of Plodia interpunctella (Hübner) and Ephestia kuehniella (Zeller) ((Lepidoptera: Pyralidae); in: International Conference on pests in agriculture, 6 - 8 January 1997 , Montpellier, pp. 783 - 792.

12. Bonning, B. C. and B. D. Hammock: Development of recombinant baculoviruses for insect control; Ann. Rev. Entomol. 41 (1996) 191 - 210.

13. Buchelos, C. T. and A. R. Levinson: Population dynamics of Ephestia elutella (Huebner) in tobacco stores with and without insecticidal treatments: a survey by pheromone and unbaited traps; $Z$. Ang. Ent. 100 (1985) 68 - 78.

14. Buchelos, C. T. and A. R. Levinson: Efficacy of multisurface traps and lasiotraps with and without pheromone addition, for monitoring and masstrapping of Lasioderma serricome F. (Col: Anobiidae) in insecticide-free tobacco stores; J. Appl. Ent. 116 (1993) 440 - 448.

15. Caramori, T., Albertini, A. M. and A. Galizzi: In vivo generations of hybrids between two Bacillus thuringiensis insect-toxin-encoding genes; Gene 98 (1991) 37 - 44.

16. Childs, D. P., Overby, J. E. and D. Niffenegger: Phosphine fumigation of flue-cured tobacco warehouse for control of the cigarette bettle; Tobacco 168 (1969) 20 - 25.

17. Crop Protection Chemicals Reference; John Wiley \& Sons, New York, 1990.
18. Devakumar, C. and S. Dev: Chemistry; in: Neem research and development, edited by N.S. Randhawa and B. S. Parmar, Society of Pesticide Science, India, 1993, pp 63-96.

19. Donegan, K. K., Schaller, D. L., Stone, J. K., Ganio, L. M., Reed, G., Hamm, P. B. and R. J. Seidler: Microbial populations, fungal species diversity and plant pathogen levels in field plots of potato plants expressing the Bacillus thuringiensis var. tenebrionis endotoxin, Transgenic Res. 5 (1996) 25-35.

20.. Douglas H. and P. D. Ross: Methoprene: Its development and use for tobacco protection; 'Tob. Int. 192 (14) (1990) 12-18.

21. European Patent Application 0448220 A1: Control of cigarette beetles; Hofer, M.: Fabriques de Tabac Reunies S. A., 25.09.1991, Bulletin 91/39.

22. Faustini, D. L., Lehmann, R. M., Long, J. S. and M. A. Manzelli: The efficacy of KABAT as a surface spray on oriental tobacco bales for control of the cigarette bettle Lasioderma serricome (F.) (Coleoptera: Anobiidae); Beitr. Tabakforsch. Int. 14 (1987) 41 - 44.

23. Federici, B. A.: Microbial insecticides; Pesticide Outlook 2 (1991) 22 - 28.

24. Feitelson, J. S.; Payne, J. and L. Kim: Bacillus thuringiensis: Insects and beyond; Bio/Technol. 10 (1992) 271 - 275.

25. Feng, Q. and W. J. Becktel: pH-induced conformational transitions of cry IA(a), cry IA(c) and cry IIIA $\delta$-endotoxins in Bacillus thuringiensis; Biochem: 33 (1994) 8521 - 8526.

26. Ferré, J., Escriche B., Bel, Y. and J. V. Rie: Biochemistry and genetics of insect resistance to Bacillus thuringiensis insecticidal crystal proteins; FEMS Microbiol. Lett. 132 (1995) 1 - 7.

27. Frowein GmbH \& Co, Technische Information: Tabakschädlinge; Albstadt, Germany, p 8.

28. Fugmann, B., Lieb, F., Moeschler, H., Naumann, K. und U. Wachendorff: Natïrliche Pflanzenschutzwirkstoffe Teil II: Grenzen der praktischen Verwertung; Chem. Zeit 1 (1992) 35 - 41.

29. Fugmann, B., Lieb, F., Moeschler, H., Naumann, K. und U. Wachendorff: Natürliche Pflanzenschutzwirkstoffe Teil I: Eine Alternative zu synthetischen Pflanzenschutzmitteln? Chem. Zeit 6 (1991) 317 - 330.

30. Gadani, F., Ayers, D. and W. Hempfling: Tobacco: a tool for plant genetic engineering research and molecular forming. Part 1; Agro-Food-Industry $\mathrm{Hi}$ Tech 1 (1995) 19 - 24.

31. Geissler, K.: Anwendung und Bedeutung insektenpathogener Viren im integrierten Pflanzenschutz; Arch. Phytopath. Pflanz. 29 (1995) 479 - 483. 
32. Gelernter, W. D.: Bacillus thuringiensis, bioengineering and the future of bioinsecticides; Brighton Crop Protection Conference - Pest and Diseases 2 (1990) 617 - 624.

33. Genève, R., Delon, R., Fleurat-Lessard, F., Hicaubé, D. and J. M. Le Torch: Comparison of different pheromone traps for the monitoring of tobacco moth Ephestia elutella (Hübner) (Lep. Pyralidae) in tobacco warehouses; Ann. Tabac 19 (1990) 65 - 77.

34. Gibbons, A.: A biopesticidal tree begins to blossom; Science 255 (1992) 1070 - 1071.

35. Goldberg, L. J. and J. Margalit: A bacterial spore demonstrating rapid larvacidal activity against Anopheles sergentii, Uranotaenia unguiculata, Culex univittatus, Aedes aegypti, and Culex pipiens; Mosquito News 37 (1977) 355 - 358.

36. Gowda, D. N., Shivanandappa, N. and C. Karegowda: Efficacy of soil amendments in control of root-knot nematodes in tobacco nursery; J. Soil Biol. Ecol. 5 (1985) 131 - 133.

37. Heeman, V.: Insect control: Natural chemicals attack beetles; Tob. Rep. 113 (1986) 38 - 40.

38. Höfte, $H$. and $H$. R. Whiteley: Insecticidal crystal proteins of Bacillus thuringiensis; Microbiol. Reviews 53 (1989) 242 - 255.

39. Hoover, K., Herrmann, R., Moskowitz, H., Bonning, B. C., Duffey, S. S., McCutchen, B. F. and B. D. Hammock: The potential of recombinant baculoviruses as enhanced bioinsecticides; Pesticide Outlook 7 (3) (1996) 21 - 27.

40. Hunter, D. K., Hoffmann, D. F. and S. J. Collier: Pathogenicity of a nuclear polyhedrosis virus of the almond moth Cadra cautella; J. Inverteb. Pathol. 21 (1973) 282 - 286.

41. Ignoffo, C. M.: Strategies to increase the use of entomopathogens; J. Invert. Pathol. 31 (1978) 1 - 3.

42. Isman, M. B.: Leads and prospects for the development of new botanical insecticides; Rev. Pestic. Toxicol. 3 (1995) 1 - 20.

43. Isman, M. B., Koul, O., Luczynski, A. and J. Kaminski: Insecticidal and antifeedant bioactivities of neem oils and their relatioship to azadirachtin content; J. Agric. Food Chem. 38 (1990) 1406 - 1411.

44. Isman, M. B.: Botanical insecticides; Pesticide Outlook 5 (3) (1994) 26 - 31.

45. Jackson, D. M., Brown, G. C., Nordin, G. L. and D. W. Johnson: Autodissemination of a baculovirus for management of tobacco budworms (Lepidoptera: Noctuidae) on tobacco; J. Econ. Entomol. 85 (1992) 710 - 719.

46. Jayaraj, S., Bharathi, M. and P.C.S. Babu: Integrated pest management. in: Neem research and development, edited by N.S. Randhawa and B.S. Parmar, Soc. of Pesticide Sci., India, 1993, 154-167.
47. Joshi, B. G., Ramaprasad, G. and S. N. Rao: Neem seed kernel suspension as an antifeedant for Spodoptera litura in a planted flue-cured Virginia tobacco crop; Phytoparasit. 12 (1984) 3 - 12.

48. Kaelin, P., Morel, P. and F. Gadani: Isolation of Bacillus thuringiensis from stored tobacco and Lasioderma serricome (F.); Appl. Environ. Microbiol. 60 (1994) 19 - 25.

49. Keever, D. W.: Reduced population growth and delayed development of the cigarette bettle (Cole. optera: Anobiidae) due to thuringiensin; 'Tob. Sci. 38 (1994) 35 - 37.

50. Keever, D. W.: Freezing of tobacco display samples for disinfestation of the cigarette bettle (Coleoptera: Anobiidae); Tob. Sci. 37 (1993) 65 - 68.

51. Kellen, W. R. and D. F. Hoffmann: Occurence of two baculoviruses in Cadra figuliella (Lepidoptera: Pyralidae); J. Invert. Pathol. 43 (1984) 439 - 440.

52. Kleeberg, H., Hummel, E., Ruch, B., Troß; R. und C. Kliche-Spory: Neem Azal-T/S-Kompromiß zwischen Wirksamkeit und Abbau; Mitt. a. d. Biol. Bundesanst. H 321 (1996) 419.

53. König, K.-H.: Fortschritte im chemischen Pflanzenschutz. Teil II: Neue Breitbandfungizide, Bioregulatoren, Pheromone; CHIIUZ 6 (1990) 292 - 302.

54. Krieg, A., Huger, A., Langenbruch, G. and W. Schnetter: Bacillus thuringiensis var. tenebrionis: a new pathotype effective against larvae of Coleoptera; J. Appl. Entomol. 96 (1983) 500 - 508.

55. Krishna Murthy, G. V. G. and K. Nagarajan: Postemergence control of Orobanche cernua on tobacco with oils; Tropical Pest Management 37 (1991) 149 151.

56. Langenbruch, G. A. and J. Huber: Förderungsmöglichkeiten für selektive mikrobiologische Pflanzenschutzmittel; Nachrichtenbl. Deut. Pflanzenschutzd. 42 (1990) 49 - 53.

57. Lee, S. M., Klocke, J. A., Barnby, M. A., Yamasaki, R. B. and M. F. Balandrin: Insecticidal constituents of Azadiracbta indica and Melia azedarach (Meli. aceae); in: Naturally occuring pest bioregulators, edited by P. M. Hedin, ACS Symposium Series 449; Washington, 1991, pp 293 - 304.

58. Leisy, D. J. and J. R. Fuxa: Natural and engineered viral agents for insect control; in: Crop protection agents from nature, edited by L. G. Copping, SCI 1996, U.K. pp. 389 - 425.

59. Li, J., Carroll, J. and D. J. Ellar: Crystal structure of insecticidal 8 -endotoxin from Bacillus thurin. giensis at $2.5 \AA$ resolution; Nature 353 (1991) 815 . 821.

60. Makanjuola, W. A.: Evaluation of extracts of neem (Azadirachta indica A. juss.) for the control of some stored product pests; J. Stored Prod. Res. 25 (1989) 231 - 237. 
61. Manzelli, M. A., Control of the cigarette beetle in stored and processed tobacco; Tob. J. Int. 6 (1987) 373 - 378.

62. Martens, J. W. M., Honee, G., Zuidema, D., van Lent, J. W. M., Visser, B. and J. M. Vlak: Insecticidal activity of a bacterial crystal protein expressed by a recombinant baculoviruses in insect cells; Appl. Environ. Microbiol. 56 (1990) 2764 2770.

63. März, U.: The economics of neem production and its use in pest control; in: Farming systems and resource economics in the tropics, Vol. 5, edited by W. Doppler, Wissenschaftsverlag Vauk, Kiel, 1989.

64. McBride, K. E., Svab, Z., Schaaf, D. J., Hogan, P. S., Stalker, D. M. and P. Maliga: Amplification of a chimeric Bacillus gene in chloroplasts leads to an extraordinary level of an insecticidal protein; Bio/Technol. 13 (1995) 362 - 365.

65. McKinlay, R. G. and M. McCreath: Some biological alternatives to synthetic insecticides for sustainable agriculture; Pesticide Outlook 6 (1995) $31-35$.

66. Merryweather, A. T., Weyer, U., Harris, M. P. G., Hirst, M., Booth, T. and R. D. Possee: Construction of genetically engineered baculoviruses insecticides containing the Bacillus thuringiensis subsp. kurstaki HD-73 delta endotoxin; J. Gen. Virol. 71 (1990) 1535 - 1544.

67. Miller, L. K.: Genetically engineered insect virus pestiçides: Present and future; J. Invert. Pathol. 65 (1995) 211 - 216.

68. Müller, F.: Insektizide, Akarizide und Nematizide p. 179; in: Schadwirkungen auf Pflanzen, edited by Hock, B. and E. F. Elstner, B. I.; Wissenschaftsverlag, Mannheim, 1988.

69. Nordin, G. L., Brown, G. C. and D. M. Jackson: Transovum transmission of two nuclear polyhedrosis viruses (Baculoviridae) by adult tobacco budworm and viral persistence on tobacco foliage; Trans. Kentucky Academy of Science $\mathbf{5 2}$ (1 - 2) (1990) 33 - 39.

70. Nordin, G.L.; Brown, G. C. and D. M. Jackson: Vertical transmission of two baculoviruses infections to the tobacco budworm, Heliothis virescens (F.) (Lepidoptera: Noctuidae) using an autodissemination technique; J. Kans. Entomol. Soc. 63 (1990) 393 - 398.

71. North Carolina Cooperative Extension Service: Flue-cured Tobacco, North Carolina State University, Information, 1993.

72. Nyouki, F. F. R. and J. R. Fuxa: Persistence of natural and genetically engineered insecticides based on Bacillus thuringiensis; J. Entomol. Sci. 29 (3) (1994) 347 - 356.
73. Patel, B. K., Chavda, J. C., Upadhyay, N. V. and C. H. Patel: Sucker control in bidi tobacco (Nicotiana tabacum $L$.) by neem oil emulsion; Tob. Res. 16 (1990) 123 - 125.

74. Possee, R. D.: Engineered viruses for pest control; Presentation during the symposium "Natural products as a source of crop protection agents $\mathrm{II}^{\mathrm{N}} 9$ - 10 December 1996, London, SCI, 1996.

75. Prakash, A. and J. Rao: Botanical pesticides in agriculture; CRC Press Inc., 1997, pp 35 - 104

76. Price, N. R.: Enzymic factors in the resistance of stored-product pests to insecticides; Biochem. Society Transact 19 (1991) $759-762$.

77. Rajendran, S. and N. Gunasekaran: Effects of phosphine fumigant on stored products; Pesticide Outlook 6 (1995) 10 - 12.

78. Rajendran S. and K. S. Narasimhan: Phosphine resistance in the cigarette beetle Lasioderma serricome (Coleoptera: Anobiidae) and overcoming control failures during fumigation of stored tobacco; Int. J. Pest Manag. 40 (1994) 207 - 210.

79. Randhawa, N. S. and B. S. Parmar: Introductory. in: Neem research and development; Society of Pesticide Science, India 1993, pp 1 - 5.

80. Rassmann, W.: Zur Bekämpfung von Larven des Tabakkäfers (Lasioderma serricorne Fab.) durch Gefrieren von Rohtabak und Tabakfertigprodukten; Anz. Schädlingskde, Pflanzenschutz, Umweltschutz 53 (1980) 133 - 155.

81. Report of an Ad Hoc Panel of the Board on Science and Technology for International Development National Research Council; Neem, a tree for solving global problems, Appendix A, Safety tests, National Academy Press, Washington, D. C., 1992.

82. Ribeiro, B. M. and N. E. Crook: Expression of fulllength and truncated forms of crystal protein genes from Bacillus thuringiensis subsp. kurstaki in a baculoviruses and pathogenicity of the recombinant virises; J. Invert. Pathol. 62 (1993) 121 - 130.

83. Rie, J. V., McGaughey, W. H., Johnson, D. E., Barnett, B. D. and H. V. Mellaert: Mechanisms of insect resistance to the microbial insecticide Bacillus thuringiensis; Science 247 (1990) 72 - 74.

84. Riemensberger, J.: Einsatzmöglichkeiten von Neern- und Melia volkensii-Präparaten zur Bekämpfung von Tabakkäfern Lasioderma serricorme Fabricius (Coleoptera: Anobiidae) und Tabakmotten Ephestia elutella Hübner (Lepidoptera: Pyralidae) in gelagertem Tabak, Diploma-Thesis, University of Bonn, 1996.

85. Rowe, G. E. and A. Margaritis: Bioprocess developments in the production of bioinsecticides by Bacillus thuringiensis; CRC critical Reviews in Biotechnology 6 (1987) 87 - 127. 
86. Ryan, L.: Post-harvest tobacco infestation control; p. 1 - 155, Chapman \& Hall, London SE1 $8 \mathrm{HN}$, UK, 1995.

87. Schmutterer, $H$. and $M$. Doll: The marrango or Philippine neem tree, Azadirachta excelsa ( $-A$. integrifoliola): A new source of insecticides with growth-regulating properties; Phytoparasit. 21 (1993) 79 - 86.

88. Shelton, A.: Insect control: What's in the pesticide arsenal? Tob. Rep. 116 (1989) 46.

89. Singh, R. P.: Bioactivity against insect pests; in: Neem research and development, Randhawa, N. S. and B. S. Parmar, Society of Pesticide Science, India, 1993, pp 109 - 122.

90. Stein, W.: Methoden der modernen Schädlingsbekämpfung im Vorratsschutz; Mitt. Gebiete Lebensm. Hyg. 83 (1992) 612 - 628.

91. Tabashnik, B. E.: Resistance to insecticides, Bacillus thuringiensis, and transgenic plants; Pesticide Outlook 8 (1995) 24 - 27.

92. Tailor, R., Tippett, J., Gibb, G., Pells, S., Pike, D., Jordan, L. and S. Ely: Identification and characterization of a novel Bacillus thuringiensis $\delta$ endotoxin entomocidal to coleopteran and lepidopteran larvae; Mol. Microbiol. 6 (1992) 1211 - 1217.

93. Vadlamudi, R. K., Weber, E., Ji, I., Ji, T. H. and L. A. Bulla Jr: Cloning and expression of a receptor for an insecticidal toxin of Bacillus thuringiensis; J. Biol. Chem. 270 (1995) 5490 - 5494.

94. Vaeck, M., Reynaerts, A., Höfte, H., Jansens, S., de Beuckeleer, M., Dean, C., Zabeau, M, van Montagu, $M$. and J. Leemans: Transgenic plants protected from insect attack; Nature 328 (1987) 33 37.

95. Van der Salm, T., Bosch, D., Honée, G., Feng, L., Munsterman, E., Bakker, P., Stiekema, W. J. and B. Visser: Insect resistance of transgenic plants that express modified Bacillus thuringiensis cry $L A(b)$ and cry IC genes: a resistance management strategy; Plant Molecular Biol 26 (1994) 51 - 59.
96. Wewetzer, A.: Zellkulturen von Azadirachta indica (A. Juss) zur Gewinnung von Azadirachtin; Mitt. a. d. Biol. Bundesanst. H 321 (1996) 422.

97. Williams, S., Friedrich, L., Dincher, S., Carozzi, N., Kessmann, H., Wand, E. and J. Ryals: Chemical regulation of Bacillus thuringiensis $\delta$-endotoxin expression in transgenic plants; Bio/Technol. 10 (1992) 540 - 543.

98. Wilson, T. G.: Transposable elements as initiators of insecticide resistance; J. Econ. Entomol. 86 (1993) 645 - 651.

99. Wilson, T. J. and H. O. Wills: Finding the best way to kill beetles; World Tobacco: Tobacco Technology for Russia and Eastern Europe, 1993, 104 . 112.

100. Yoshida, H. A. and N. C. Toscano: Comparative effects of selected natural insecticides on Heliothis virescens (Lepidoptera: Noctuidae) Larvae; J. Econ. Entomol. 87 (1994) 305 - 310.

101. Zettler, J. L. and D. W. Keever: Phosphine resistance in cigarette bettle (Coleoptera: Anobiidae) associated with tobacco storage in southeastern United States; J. Econ. Entomol. 87 (1994) 546 550.

Author's address:

Verband der Cigarettenindustrie

Königswinterer Straße 550

D. 53227 Bonn 